\title{
ORGANIZATIONAL FACTORS AFFECTING EMPLOYEE'S MOTIVATION AND PRODUCTIVITY IN BANGLADESHI SATELLITE TELEVISION CHANNELS
}

\author{
Md. Al Amin Khan'i, \\ Arun Kumar Tarofder², \\ S. M. Ferdous Azam ${ }^{2}$ \\ ${ }^{1}$ Postgraduate Centre (PGC), \\ Faculty of Business Management, \\ and Professional Studies (FBMP), \\ Management and Science University, \\ Malaysia \\ ${ }^{2}$ Faculty of Business Management \\ and Professional Studies (FBMP), \\ Management and Science University, \\ Malaysia
}

\begin{abstract}
:
The article illustrates the connection between organizational factors that influence on employee's motivation and productivity in a given organization satellite TV channel in Bangladesh. The exploration surveys important writing to distinguish the organizational factors that impact representative inspiration and their output also. Be that as it may, the connection between organizational components and employee's efficiency is yet to be seen thoroughly. The examination investigates view of hierarchical components like reward system, training and jobs security and the representative efficiency. The example is of significant fluctuation as far as gender, educational level, salary and employment tenure. Information investigations were performed utilizing SPSS 23.0, and the outcomes demonstrate that employee inspiration have a significant positively influence on by and large employee profitability in a satellite TV station.
\end{abstract}

JEL: L10; L96; J01

Keywords: organizational factors, employee motivation, productivity, satellite television channel, Bangladesh

i Correspondence: email alamin.mkt@gmail.com 


\section{Introduction}

The reason for this article is to inspect organizational elements that forever sway on worker's inspiration and their profitability in like manner in a satellite TV station in Bangladesh. In Bangladesh, 45 Satellite TV station has gotten the permit from the administration. At the present time 30 satellite TV stations are passing on in the nation.

All businesses need their representatives to perform as well as could be expected thus make careful arrangements in guaranteeing that they give all the important assets and a decent workplace to keep their representatives motivated (Onyeonoro and Nwokorie, 2014).

There are numerous administrators in a TV station who really don't have the foggiest idea about the genuine situation why their representatives are not working sufficient. They generally have given work strain to their specialist as it were. The high official figures overpressure may affect on better efficiency. Nonetheless, most administrators don't have an away from of what really motivate their representatives (Loedolff, Erasmus, Van, Mda, and Nel, 2013).

It is evident that, how to do the workplace, leadership style, job structure, performance framework and training, and improvement influence employees' motivation in a satellite TV channel in Bangladesh. Wijewantha (2020) it is prescribed that the company need to consider employee's prosperity, as it prompts a variety of worker level results.

Lepak et al. (2006) seen that organizational condition impacts representatives' perspectives and practices and henceforth their profitability as well. If employees feel that what they state, or think doesn't make a difference definitely the board will misfortune their workers productivity. High official of organization must need to regard their workers' voice. Express gratitude for their diligent employee with the goal that they can have a sense of security and improve as past.

The reason for this exploration is, therefore, to investigate and incorporate the relations between authoritative elements, for instance reward framework stablish to impact the both the individuals who are working better and even not well entertainer also. There has another significant subject of hierarchical elements that is training, without a doubt can say it is an imperative issue that will work for the representative's expertise advancement and job stability additionally the reality to be increasingly profitable.

\section{Literature Review}

\subsection{Motivation}

Motivation, in any organization, is very vital to accomplishment of administrative aims. As such, it is a fundamental issue by applying effective styles of organizational factors (Zareen et al., 2015). It is defined that, for execution and occupation fulfillment employee motivation is the key factor (Wicker, 2011; Pinder, 2014). 
To represent the organizational components, it is discovered that for a better yield of a representatives certainly organizational factors assume a significant job in a TV channel specially satellite station. The connection between a worker's inspiration and their working profitability is presently analyzed. Various specialists (Heneman et al., 1988; Igalens and Roussel, 1999; Pool, 1997) have reasoned that work inspiration and representative profitability ought to be dealt with independently, so factors of impact can be all the more promptly recognized and to allow for better understanding.

In a satellite TV channel, it is essential to persuade representative as it's a private station, so they need to rely upon the advertiser for income. So, rousing representatives can decidedly go to accomplish their work like program making, news inclusion and so on. Consequently, worker inspiration assumes a central job in any kinds of organization (Wasike and Ndivo, 2015).

\subsection{Productivity}

Generally, the idea of efficiency indicates the proportion of ratio to input. In a satellite TV channel, it is must need to estimate the worker profitability for organizational betterment. Productivity is a significant part of a company (Pritchard, 1992 in Pritchard et al., 2008; de Been et al., 2017). At the individual level, work profitability is the representatives' ability to create items or administrations needed to accomplish association goals. A high work profitability would improve association execution (Huselid, 1995; Prakash et al., 2017) with the end goal that associations will look for the most ideal approaches to upgrade their representatives' efficiency to create positive and sustainable effects.

\subsection{Motivation and Employee Productivity}

Shields, M. (1988) recommended that, employee inspiration in a work is evaluated. The primary speculations were those of individual needs, value and hope/esteem. This is trailed by an assessment of the relationship among motivation and techniques for employment and work plan. These incorporate the impact of environmental factors, for example, machine-driven development and financial slump, the nature of the advanced education framework and the client network. This is trailed by an investigation of library staff perspectives and the idea of library work. The division among proficient and nonproficient staff is viewed as especially significant in this unique circumstance.

Despite the theory and models utilized, this exploration checked on past examinations on the part of worker inspiration and their profitability. Past look into has indicated that representative cooperation is decidedly related worker profitability. Inspired representatives give additional consideration and time to their work, they make function as a part of their life; take hierarchical goals as their very own objectives and feel fulfilled while accomplishing them.

A Randstad study found that 58 percent of employees would leave their job on account of negative office governmental issues, as this influence numerous parts of work culture: the measure of work put in, what sort of attitude employees have and employee maintenance (www.business.com) 
An employee's workplace impacts their state of mind, drive and by and large execution in their organization. The thought is basic - give your representatives a steady workplace, and they'll be productive.

Worker incitement and business satisfaction devise gotten unfathomable thought in vogue various fields and different past analysts have found a positive association among motivation and occupation satisfaction; the more specialists are prodded, the more imperative their movement satisfaction (Suttikun et al., 2018).

It is proposed that workers need judicious treatment and reasonable evaluation in regards to the HR rehearses, so the organization needs to bring reasonable strategy and impart it to their employees. Reward ought to be granted on merit premise and advancement ought to be on status and sincerity both, which help underway and maintenance. The region of workplace found that it is a key factor in employees' inspiration, it is additionally discovered that worker leaves the activity because of workplace (Irshad and Afridi, 2011)

The office for advancement can be evaluated by the level of motivation and inspiration a company offers to their worker permitting them to advanced work then always tendency of extra work made (Martins and Terblanche, 2003). And another important role is to influence coworker as well to do the same as a motivated employee. Iva Cary (2020) It might sound clear that employees ought to have the appropriate degree of training so as to carry out their responsibility successfully and productively, yet this is perhaps the biggest issue where employers are not giving focus and taking action accordingly. They think it's a waste of money or even they are not amiable for spending money to develop skill of their employee's. If they think long run it is obvious that trained employee gives more productive but instead of that most of the employer has claimed that their employees are less productive in the workplace. Working environment is another most widely recognized reason for employee motivation and their productivity accordingly.

\section{Methodology}

This investigation utilized Likert scale 1-5 estimation of survey and dispersed 338 representatives of satellite TV stations in Bangladesh. In this exploration the survey was in electronic poll design that is a Google Form. This research implemented a quantitative method research where has a closed ended questionnaire. The examination depended on primary information.

A simple random testing approach is proposed for this examination in elegant of the fact that the game plan is to be defined for the satellite TV employees. The sample size uses dependable guidelines. This examination furthermore guided validity and reliability test to ensure the validity and reliability of the questionnaire's with Cronbach's $\alpha$ coefficient in the Statistical package for Social Science (SPSS) programming (rendition 23) 


\subsection{Research Framework}

The research framework was created on the basis of previous studies, and it is given underneath in Figure 1.

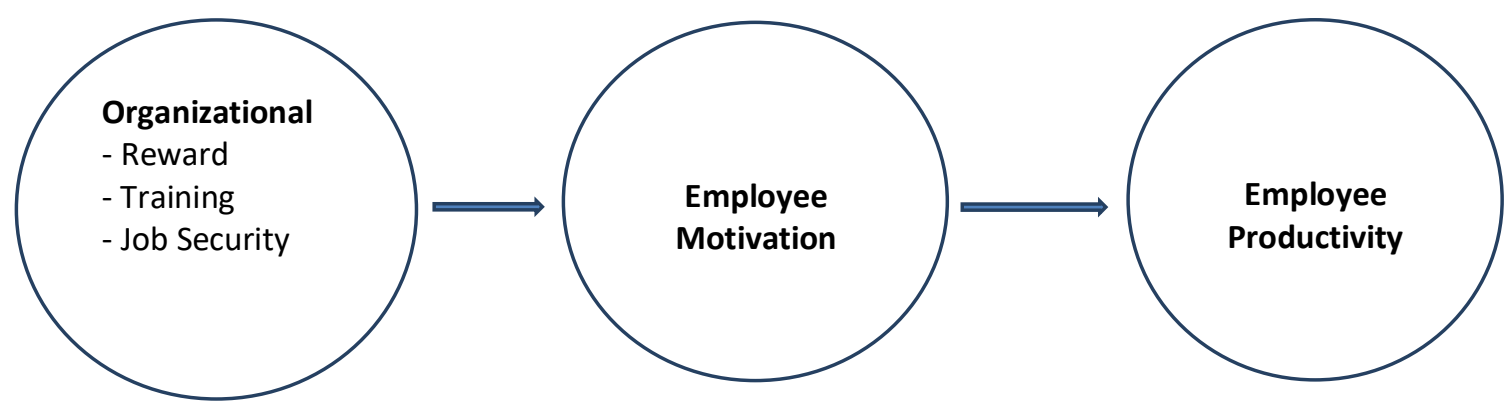

Figure 1: Proposed Research Model

\subsection{Organizational Factors}

An organizational factor assumes an imperative job for spurring representatives in the organization and that drive to worker profitability appropriately, extraordinarily in a satellite TV channel. Maximum company have not kept up the fundamental principles of representative inspiration, for example, reward framework that is in reality right of an employee, good working condition and legitimate preparing and charming pioneers among others (Akinwale, 2019).

Ketkar and Sett (2010) found that organizational culture influences worker productivity. The motivation of employees in the working environment in spite of everything remains one of the fragile subjects that choose the level of data that delegates will put in the relationship to concentrate on incredible execution.

It is discovered that numerous organizational variables are affecting motivation by implication additionally however reward such a factor, that is hit legitimately on representative inspiration lastly it is affecting profitability too (Kalimullah et al, 2010).

As indicated by Harrison (2005), "Training and advancement in the zone of human asset the executives manage hierarchical activities planned for upgrading the presentation of individual specialists and gatherings in a work setting. It is likewise distinguished by various names, including human asset improvement, learning and advancement, and representative turn of events."

Simultaneously, the mentees will learn all the more rapidly the best approach to work viably in and adjust to, another workplace Ann, S. what's more, Blum, S. (2020).

Andra (2019) affirms that lack of financial issues, job instability and now and again serious occupation market may compel the channel workers to get an overburden. It is seen that a minimized outstanding task at hand is one of the critical reasons for worry among workers. It is an authoritative issue if a pioneer can't comprehend this issue in that time their representatives may lose their inspiration and unquestionably it will affect on their efficiency. At long last, looser will be the management also. It is seen that for lessening the representatives stress they can workshop and diverse social enacts. 
Additionally, a healthy organization should think for rewarding their employees who are doing better. Everybody works in desire for certain rewards, and government assistance is one of them. So as to comprehend the effect of employee's advantage programs have more prominent effect on work-inspiration than on productivity. It is evident that, in a satellite television channel, distinctive sexual orientation and education see various sorts of advantages, also, more youthful representatives affected more than others (Jon-Chao Hong et al., 1995). Quick difference in the current working life is related with expanding requests of learning new talents, need to adjust to new sorts of work, weight of higher efficiency and nature of work, time pressure and uncontrolled jobs and with developing mental remaining task at hand and worry among the employees. Such improvements require higher need to be given for mental nature of work and the work environment, and more thoughtfulness regarding psychosocial parts of work.

Health at work and sound workplaces are among the most significant resources of people, networks and nations. Word related wellbeing is a significant system not exclusively to assurance the safety of employees, yet in addition to con-tribute decidedly to efficiency, nature of substances, employee stimulus, job fulfillment then accordingly to the general personal satisfaction of people and society (WHO, 1994).

Now, working system in every organization is very much competitive. Same thing is happening in a satellite tv channel also. People need to be more skilled and smarter enough to fight for the organization in future. Without training it is tough to gain technical specialist also. If he or she becomes well skilled, definitely he or she will perform more for the organization (Gomez et al., 1995)

To accomplish the arrangement of targets of this examination, these three-theory given beneath were proposed and attempted;

H1: Reward is significantly affected employees' motivation.

H2: Training and advancement framework influence employee's' inspiration and their profitability.

H3: Job stability framework can fundamentally influence employee's' inspiration and their efficiency.

\subsection{Demographic details}

An examination of Table 1 shows that $90.5 \%$ are male respondents. It likewise uncovers that respondents between 31-40 years old establish the biggest number (56.8\%). While representatives at the instructive level are most of the respondents in that examination is $(77.5 \%)$, the individuals who have worked over five years establish the lion's share as for long stretches of understanding (79\% generally). 
Md. Al Amin Khan, Arun Kumar Tarofder, S. M. Ferdous Azam ORGANIZATIONAL FACTORS AFFECTING EMPLOYEE'S MOTIVATION AND PRODUCTIVITY IN BANGLADESHI SATELLITE TELEVISION CHANNELS

Table 1: Demographic Profile of Respondents

\begin{tabular}{|c|c|c|c|c|}
\hline & Frequency & Percent & Valid Percent & Cumulative Percent \\
\hline \multicolumn{5}{|l|}{ Age } \\
\hline Less than 30 years & 43 & 12.7 & 12.8 & 12.8 \\
\hline $31-40$ years & 193 & 56.5 & 56.8 & 69.6 \\
\hline $41-50$ years & 93 & 27.5 & 27.7 & 97.3 \\
\hline More than 51 years & 9 & 2.7 & 2.7 & 100.0 \\
\hline Total & 338 & 99.4 & 100.0 & \\
\hline \multicolumn{5}{|l|}{ Gender } \\
\hline Male & 306 & 90.5 & 90.5 & 90.5 \\
\hline Female & 32 & 9.5 & 9.5 & 100.0 \\
\hline Total & 338 & 100.0 & 100.0 & \\
\hline \multicolumn{5}{|l|}{ Education } \\
\hline Under Secondary education & 4 & 1.2 & 1.2 & 1.2 \\
\hline Secondary education & 4 & 1.2 & 1.2 & 2.4 \\
\hline Higher Secondary education & 7 & 2.1 & 2.1 & 4.4 \\
\hline Graduation & 59 & 17.5 & 17.5 & 21.9 \\
\hline Master's degree & 262 & 77.5 & 77.5 & 99.4 \\
\hline $\mathrm{PhD}$ & 2 & .6 & .6 & 100.0 \\
\hline Total & 338 & 100.0 & 100.0 & \\
\hline \multicolumn{5}{|c|}{ Employment - Total years of work experience } \\
\hline $1-5$ years & 56 & 16.6 & 16.6 & 16.6 \\
\hline $5-20$ years & 267 & 79.0 & 79.2 & 95.8 \\
\hline More than 21 years & 15 & 4.1 & 4.2 & 100.0 \\
\hline Total & 338 & 100.0 & 100.0 & \\
\hline
\end{tabular}

\subsection{Hypothesis Test}

\subsubsection{Hypotheses test for direct effect}

Hypothesis test in this research is measured based on significant value. Here the hypothesis test is for direct effect.

\begin{tabular}{|l|l|c|}
\hline $\mathbf{H}(\mathbf{x})$ & Hypothesis & Findings \\
\hline H1 & Reward is significantly affected employees' motivation. & Accepted \\
\hline H2 & $\begin{array}{l}\text { Training and advancement framework influence employee's' inspiration and their } \\
\text { profitability }\end{array}$ & Accepted \\
\hline H3 & $\begin{array}{l}\text { Job stability framework can fundamentally influence employee's' inspiration and } \\
\text { their efficiency }\end{array}$ & Accepted \\
\hline
\end{tabular}

\section{Discussion}

This article has given a fundamental results where some investigations have connected the relationship between the organizational factors like reward system for a better performance, regular basis training arrangement for ability improvement for employees and job stability for giving more concentration of employee to work and finally these variables are straightforwardly effects on their productivity in a company (Bakotic and Babie, 2013; Chamal and Dilina, 2018; Chaudhury, 2015; Edem et al., 2017; Edoho et al., 
2015). It is not only demonstrated here and talked about additionally in a literature review as well. In Bangladesh, employees of a private tv channel who are really will upbeat when they get the performance reward and they always think a secured job also, if it is ok, they feel happy. Largely, all the proposed hypotheses were emphatically identified with the employee motivation of satellite television channel in Bangladesh.

\section{Conclusion}

This study examines the implications of organizational different aspects on employee's motivation and their job productivity in a satellite television channel. We find constructive associations concerning the working environment, leadership style, training, and others as an organizational factor as well as salary, compensation especially fair wages and many other components works as an organizational factor which are directly reflecting on motivation and productivity. One of the most interesting findings is that Organizational factors are more important for employee's motivation and productivity accordingly rather than economic. In this article only few components are considered as an organizational factor but there have many components in organizational factors. As per Papalexandris and Bourantas (2003, p.315), although "employees' assessment is an important factor, which is connected with the company drawn out progress, it is poorly applied by the organizations." Thus, the ends got from the thoughts could help companies reexamine the variables that influence employee productivity. Specifically, an association's top administration should concentrate on both the degree of support that their officials provide for employees and how this support is spread and interpreted inside the authoritative condition in which employees perform.

\section{References}

Akinwale, O. E. (2019). Employee voice: speaking up in the organisation as a correlate of employee productivity in the oil and gas industry - an empirical investigation from Nigeria, Serbian Journal of Management, Vol. 14 No. 1, pp. 97-121.

Andreea Tutu, Ticu Constantin (2011). Understanding Job Performance Through Persistence and Job Competency. Procedia - Social and Behavioral Sciences. Volume 33, 2012, Pages 612-616

Ann, S. And Blum, S. (2020). Motivating Senior Employees in The Hospitality Industry", International Journal of Contemporary Hospitality Management, Vol. 32 No. 1, Pp. 324-346.

Bakotic, D. and Babie, T. (2013). The relationship between the working condition and job satisfaction: the case of Croatian shipbuilding company, International Journal of Business and Social Science, Vol. 4 No. 2, pp. 23-35. 
Chamal, G. S. and Dilina, H. (2018). Employee satisfaction and related factors among public health workers in Sri-Lanka: a case study on regional directorate of Hambanthota, JOJ Nurse Health Care, Vol. 8 No. 4, pp. 1-7.

Chaudhury, S. (2015). Job satisfaction of hospital staff: an emerging challenge, Medical Journal of Dr. D.Y. Patil University, Vol. 8 No. 2, pp. 129 -138.

Donné Close, N. Martins (2015). Generational Motivation and Preference for Reward and Recognition. Journal of Governance and Regulation, Volume 4, Issue 3, 2015.

Edem, M. J., Akpan, E.U. and Pepple, N. M. (2017). Impact of workplace environment on health workers, Occupational Medicine and Health Affairs, Vol. 5 No. 2, pp. 1-5.

Edoho, S. P., Bamidele, E. O., Neji, O. I. and Frank, A. E. (2015). Job satisfaction among nurses in public hospital in calabar, Cross River state, Nigeria, America Journal of Nursing Science, Vol. 4 No. 4, pp. 231-237.

Elizabeth Boye Kuranchie-Mensah, Kwesi Amponsah-Tawiah (2015). Journal Of Industrial Engineering And Management Jiem, 2016 - 9(2): 255-309 http://dx.doi.org/10.3926/jiem.1530

Gaspary, E., De Moura, G. L. And Wegner, D. (2020). How Does the Organisational Structure Influence a Work Environment for Innovation?, Int. J. Entrepreneurship And Innovation Management, Vol. 24, Nos. 2/3, Pp.132-153.

Gomez-Mmejia, L. R., Balkin, D.B. and Cardy, R.L. (1995). Managing human resources. Englewood cliffs, NJ: Prentice-Hall, Inc.

Heneman, R. L., Greenberger, D. B. and Strasser, S. (1988). The relationship between payfor-performance perceptions and pay satisfaction, Personnel Psychology, Vol. 41 No. 4, pp. 745-59.

Huselid, M. A. (1995). The impact of human resource management practices on turnover, productivity, and corporate financial performance, Academy of Management Journal, Vol. 38 No. 3, pp. 635-672.

Igalens, J. and Roussel, P. (1999). A study of the relationship between compensation package, work motivation and job satisfaction, Journal of Organisational Behaviour, Vol. 20 No. 7, pp. 1003-25.

Iva Cary (2020). 6 Ways to Improve Employee Productivity In 2020. Retrieved from https://scholarlyoa.com/6-ways-to-improve-employee-productivity-in-2020/

Jon-Chao Hong, Sung-De Yang, Li-Jung Wang, En-Fu Chiou, Fan-Yin Su sui-Lan Huang, (1995). Impact of employee benefits on work motivation and productivity, International Journal of Career Management, Vol. 7, Issue 6.

Kamalian, A. R., Yaghoubi, N. M., \& Moloudi, J. (2010). Survey of Relationship between Organizational Justice and Empowerment (A Case Study). European Journal of Economics, Finance and Administrative Sciences, 24, 165-171.

Ketkar, S. and Sett, P. K. (2010). Environmental dynamism, human resource flexibility, and firm performance: analysis of a multi-level causal model, International Journal of Human Resource Management, Vol. 21 No. 8, pp. 1173-1206.

Kuranchie-Mensah, Elizabeth Boye; Amponsah-Tawiah, Kwesi (2016). Employee Motivation and Work Performance: A Comparative Study of Mining Companies 
in Ghana, Journal of Industrial Engineering and Management (Jiem), Vol. 9, Iss. 2, pp. 255-309, http://dx.doi.org/10.3926/jiem.1530

Lepak, D., Liao, H., Chung, Y. and Harden, E. (2006). A conceptual review of human resource management systems in strategic human resource management research, Research in Personnel and Human Resources Management, Vol. 25, pp. 217-271.

Loedolff, P., Erasmus, B. J., Van, Z., Mda, M., and Nel, P. S. (2013). Managing training and development in South Africa (6th ed.). Cape Town, South Africa: Oxford University Press.

Mohammd Abuhashesh, Rand Al-Dmour And Ra'ed Masa'deh (2019). Factors That Affect Employees Job Satisfaction and Performance to Increase Customers' Satisfactions, Journal of Human Resources Management Research, Vol. 2019 (2019), Article Id 354277, Doi: 10.5171/2019.354277

Morkevičiūtė, M. and Endriulaitienè, A. (2020). Explaining work motivation through perceived transformational leadership: what to expect in a sample of female employees?, Gender in Management, Vol. ahead-of-print No. ahead-of-print. https://doi.org/10.1108/GM-01-2020-0004

Muhammad Irshad, Fahad Afridi (2011). Factors Affecting Employees Retention: Evidence from Literature, Abasyn Journal of Social Sciences. Vol.4, No.2

Namrita Kalia And Bhawana Bhardwaj (2019). Contextual and Task Performance: Do Demographic and Organizational Variables Matter? Rajagiri Management $\begin{array}{llllll}\text { Journal, } & \text { Vol. } & 13 & \text { No. } & 2, & 2019\end{array}$ pp. 30-42.

Nurun Nabi, Islam M., Dip Tm, Hossain A. (2017). Impact of Motivation on Employee Performances: A Case Study of Karmasangsthan Bank Limited, Bangladesh. Arabian J Bus Manag Review 7: 293. Doi: 10.4172/2223-5833.1000293

Onyeonoro, C. O. and Nwokorie, E. C. (2014). The impact of leadership style on effective human resources management and productivity in hospitality organizations. Multi-disciplinary Journal of Technical Education and Management Science (Kogi State University, Akungba), 9(3), 106-125.

Papalexandris, N. and Bourantas, D. (2003). Human Resource Management, Benos Publishing, Athens.

The Effects of a Heavy Workload on Employees. (2020). Retrieved 29 October 2020, from https://bizfluent.com/info-8178431-effects-heavy-workload-employees.html.

Prabhashini Wijewantha (2020). Relationship Between Perceptions of Organizational Politics (POPs) and Employee Well-being (EWB). IOSR Journal of Business and Management (IOSR-JBM), 22(5), pp. 30-38.

Pritchard, R. D., Harrell, M. M., Diaz Granados, D. and Guzman, M. J. (2008). The productivity measurement and enhancement system: a meta-analysis, Journal of Applied Psychology, Vol. 93 No. 3, pp. 540-567.

Ramos-Galarza, C. And Acosta-Rodas, P. (2019). Stress And Productivity In Workers Of Textile Companies, Lournal Of Fashion Marketing And Management, Vol. 23 No. 1, Pp. 17-29. 
Sharma, V. (2015). Imperfect Work Conditions in Bangladesh Rmg Sector, International Journal of Law and Management, Vol. 57 No. 1, Pp. 28-37.

Shields, M. (1988). Work and Motivation in Academic Libraries, Library Management, Vol. 9 No. 2, Pp. 2-33.

Stringer, C., Didham, J. And Theivananthampillai, P. (2011). Motivation, Pay Satisfaction, and Job Satisfaction of Front-Line Employees, Qualitative Research in Accounting \& Management, Vol. 8 No. 2, Pp. 161-179.

Tsai, C.-W. (2008). Leadership style and employee's job satisfaction in international tourist hotels, Woodside, A.G. (Ed.) Advances in Culture, Tourism and Hospitality Research (Advances in Culture, Tourism and Hospitality Research, Vol. 2), Emerald Group Publishing Limited, Bingley, pp. 293-332. https://doi.org/10.1016/S1871-3173(08)02005-3

Wasike, C. K. \& Ndivo, R. M. (2015). Efficacy of motivation strategies in addressing employee motivation needs in Kenya's hotel sector. African Journal of Hospitality, Tourism and Leisure, 4(1):1-10.

Who (1994). Global Strategy on Occupational Health for All: The Way to Health at Work. Geneva.

Wicker, D. (2011). Job satisfaction: Fact or fiction. Bloomington, IN: Author House. 
Md. Al Amin Khan, Arun Kumar Tarofder, S. M. Ferdous Azam

ORGANIZATIONAL FACTORS AFFECTING EMPLOYEE'S MOTIVATION AND

PRODUCTIVITY IN BANGLADESHI SATELLITE TELEVISION CHANNELS

Creative Commons licensing terms

Authors will retain copyright to their published articles agreeing that a Creative Commons Attribution 4.0 International License (CC BY 4.0) terms will be applied to their work. Under the terms of this license, no permission is required from the author(s) or publisher for members of the community to copy, distribute, transmit or adapt the article content, providing a proper, prominent and unambiguous attribution to the authors in a manner that makes clear that the materials are being reused under permission of a Creative Commons License. Views, opinions and conclusions expressed in this research article are views, opinions and conclusions of the author(s).Open Access Publishing Group and European Journal of Economic and Financial Research shall not be responsible or answerable for any loss, damage or liability caused in relation to/arising out of conflict of interests, copyright violations and inappropriate or inaccurate use of any kind content related or integrated on the research work. All the published works are meeting the Open Access Publishing requirements and can be freely accessed, shared, modified, distributed and used in educational, commercial and non-commercial purposes under a Creative Commons Attribution 4.0 International License (CC BY 4.0). 